\title{
POTENSI DAN HABITAT TEMPAT TUMBUH KETAK (Lygodium circinnatum (Burn. F.) Swartz) DI LOMBOK (Potency and Growth Habitat of Lygodium circinnatum (Burn. F.) Swartz) in Lombok)
}

\section{Wayan Widhana Susila, Ogi Setiawan dan/and M. Hidayatullah ${ }^{1}$}

\author{
${ }^{1}$ Peneliti pada Balai Penelitian dan Pengembangan Teknologi HHHBK Mataram \\ Jln. Dharma Bhakti No. 7, Ds Langko, Kecamatan Lingsar - Lombok Barat - NTB 83371, \\ Telp (0370) 6175552, Fax (0370) 617582 \\ E-mail: widhiana_susila@yahoo.co.id; dayat_kpg@yahoo.com
}

Tanggal diterima: 20 September 2018; Tamggal direvisi: 14 Oktober 2019; Tanggal disetujui: 4 Desember 2019

\begin{abstract}
Ketak (Ligodium circinnatum) is a superior Non-Timber Forest Product in West Nusa Tenggara. The research aimed to obtain data on potential, distribution, and growth habitat of ketak in Lombok Island. The study was conducted by purposive sampling inventory; the first line took randomly and the next line took systematically. Ketak was found in the Malimbu and Pusuk Forest (West Rinjani Protected Forest Management Unit (PFMU)), while in the East Rinjani PFMU was found in Lang-lang, Mentareng, and Obel-Obel. The potency for ketak in Lombok is relatively low i.e. 443 clumps/ha, 5.2 tendrils/clump and harvested aged 3 tendrils/clump. Any trees be able as climbing tree. Ketak grows well at altitude of less than $400 \mathrm{~m}$ above sea level, sloping to steep slopes, climate types $C$ to E, rainfall 935 to $1,511 \mathrm{~mm} /$ year, temperatures $24-32^{\circ} \mathrm{C}$, humidity $50-88 \%$, and light intensity 120 to 3,872 luxs. Ketak growths in soil characteristic as follow:granular structure, sandy texture, slightly acid to neutral $\mathrm{pH}$, good absorption rate, and growth capability under low nutrient level.
\end{abstract}

Keywords: Potency, Lygodium circinatum, growth habitat, tendrils, climbing trees

\begin{abstract}
ABSTRAK
Ketak (Ligodium circinnatum) merupakan jenis Hasil Hutan Bukan Kayu unggulan di Nusa Tenggara Barat. Saat ini terjadi penurunan suplai bahan baku untuk kerajinan ketak di Lombok. Penelitian bertujuan untuk memperoleh informasi potensi, sebaran, dan tempat tumbuh ketak di Pulau Lombok. Penelitian dilakukan dengan cara inventarisasi dengan metode sampling secara purposif dan peletakan jalur (transek) pertama secara acak, kemudian jalur berikutnya secara sistematis. Rumput ketak ditemukan di Kawasan Hutan Malimbu dan Pusuk (Kesatuan Pemangkuan Hutan Lindung (KPHL) Rinjani Barat), sedangkan di KPHL Rinjani Timur ada di Kawasan Hutan Lang-lang, Mentareng, dan Obel-Obel. Potensi ketak di Lombok relatif rendah dengan jumlah rumpun 443 rumpun/ha, jumlah sulur 5,2 batang sulur/rumpun dan jumlah sulur yang siap dipanen 3 batang/rumpun. Semua jenis pohon bisa menjadi pohon pemanjat rumput ketak. Di Nusa Tenggara Barat rumput ketak mampu tumbuh diketinggian kurang dari 400 mdpl, lereng landai sampai curam, tipe iklim C sampai E menurut Schmidt dan Fergusson, curah hujan 935-1.511 mm/tahun, temperatur $24-32^{\circ} \mathrm{C}$, kelembaban50-88\%, intensitas cahaya 120 3.872 lux. Ketak tumbuh pada kondisi tanah dengan struktur granuler, tekstur fraksi
\end{abstract}


berpasir, $\mathrm{pH}$ tanah agak asam sampai netral, laju resapan air baik, dan bisa tumbuh baik sampai kondisi hara rendah.

Kata kunci : Potensi, ketak, tempat tumbuh, sulur, pohon pemanjat

\section{PENDAHULUAN}

Rumput ketak (Lygodium circinnatum (Burn. F.) Swartz) merupakan sejenis paku-pakuan yang tumbuh baik di Nusa Tenggara Barat (NTB). Ketak merupakan salah satu produk unggulan di NTB. Batang sulur ketak (rimpang) digunakan sebagai bahan baku industri kerajinan anyaman di Lombok dan Bali. Produk kerajinan anyaman seperti keranjang tas, nampan, tempat buah, dan perlengkapan lain yang dijual sebagai souvenir. Kerajinan dari produk rumput ketak ini selain laku di tingkat lokal, juga sudah dieksporke negara Jepang, Thailand, Eropa (Aji, Sutriono \& Taufik, 2012).

Usaha kerajinan anyaman ketak di Lombok dihadapkan pada permasalahan penurunan dan ketidakpastian suplai bahan baku. Menurut Siregar, Ardaka, \& Hartutiningsih, (2014) keberadaan ketak di alam cenderung mengalami penurunan.Hal ini dikarenakan pemanenan secara terusmenerus dari alam, sedangkan budidayanya belum banyak dilakukan. Studi kelimpahan ketak di kebun/ladang masyarakat di desa Batudulang Sumbawa sudah dilakukan oleh Yuyun (2015). Namun belum ada informasi mengenai potensi ketak yang dipanen dari kawasan hutan di NTB.

Berdasarkan data dari Dinas Perindustrian dan Pedagangan NTB, bahwa produk kerajinan dari anyaman rumput ketak terdapat dienam Kabupaten di NTB yaitu Kabupaten Bima, Dompu, Lombok Barat, Lombok Tengah, Lombok Utara,dan Lombok Timur dengan Unit Usaha 15.649 buah dan dapat menampung tenaga kerja sebanyak 26.331 orang (Tauhid, 2012). Informasi potensi ketak di habitat alam menjadi penting guna mengetahui sejauhmana persediaan ketak dari kawasan hutan NTB yang mampu memasok ke industri pengrajinnya. Tujuan penelitian ini adalah untuk mengetahui potensi dan sebaran ketak di Pulau Lombok. Diharapkan hasil penelitian ini menjadi bahan rujukan bagi pihak terkait untuk mengawasi dan mendukung kesinambungan usaha kerajinan anyaman berbasis rumput ketak.

\section{METODOLOGI}

\section{A. Lokasi Penelitian}

Penelitian dilakukan pada dua wilayah Kesatuan Pengelolaan Hutan Lindung (KPHL) yaitu: a). KPHL Rinjani Barat (Kawasan Hutan Malimbu dan Kawasan Hutan Pusuk) dan b). KPHL Rinjani Timur (Hutan Langlang, Obelobel, dan Kawasan Hutan Mentareng). Kegiatan penelitian dilaksanakan pada bulan Juni sampai Desember 2016.

\section{B. Metode}

\section{Eksplorasi potensi dan sebaran ketak}

Penelitian dilakukan secara purposive sampling. Lokasi dan jalur (transek) pertama dipilih secara acak, kemudian jalur berikutnya secara sistematis (systematic with random start sampling).

Tahapan kegiatan meliputi: a) ekplorasi yaitu penelusuran keberadaan rumput ketak, menentukan koordinat serta pengamatan parameter kondisi biofisik tempat tumbuh; b) inventarisasi menggunakan Petak Ukur (PU) berbentuk persegi ukuran $5 \times 4 \mathrm{~m}$. Pembuatan PU dilakukan secara kontinu sehingga membentuk jalur sepanjang $100 \mathrm{~m}$. Penempatan plot pada setiap jalur dilakukan secara kontinu dimana antara PU saling menyambung. Pada masingmasing lokasi dibuat antara 5 hingga 6 jalur dengan jarak antara jalur sebesar 50 
m. Intensitas sampling (IS) adalah 15$20 \%$ dari luasan areal. Intensitas sampling $20 \%$ diambil jika potensi ketak tinggi.

Ketak tersebar secara tidak merata disejumlah lokasi di dalam kawasan KPHL Rinjani Barat dan Rinjani Timur dalam bentuk spot-spot. Jumlah plot yang dibuat di KPHL Rinjani Barat sebanyak 871 PU dengan total luas plot 1,74 ha, sedangkan di KPHL Rinjani Timur sebanyak 880 PU dengan total luas plot 1,76 ha. Parameter yang diukur adalah rata-rata jumlah rumpun per hektare, jumlah individu ketak yang bisa dipanen per rumpun, jumlah permudaan ketak per rumpun, diameter batang sulur ketak. Kriteria rumput ketak masuk kategori permudaan yaitu semua batang sulurnya yang belum bisa dipanen.

\section{Analisis tanah}

Pada kegiatan ini juga dilakukan pengambilan sampel tanah untuk mengetahui kondisi habitat rumput ketak. Pengambilan sampel tanah dilakukan secara komposit dengan memperhatikan keseragaman areal atau hamparan. Analisis tanah dilakukan di Laboratorium Tanah BPPT Mataram.Parameter yang dianalisis adalah sifat fisik dan kimia tanah $(\mathrm{pH}, \mathrm{N}$, $\mathrm{P}, \mathrm{K}$, bahan organik, KTK, dan tekstur tanah).

\section{Pengambilan data iklim}

Selain itu juga dilakukan pengambilan data kondisi iklim dengan parameter yang meliputi tipe iklim, curah hujan, temperatur, dan kelembaban.

\section{Analisa data}

Beberapa analisis yang dilakukan dalam penelitian ini, sesuai dengan tujuan penelitian, yaitu :

1. Analisis spasial. Analisis spasial meliputi penataan atau ploting lokasi sebaran rumput ketak berdasarkan hasil eksplorasi (peta sebaran ketak).
2. Analisis potensi rumput ketak. Potensi yang dihitung adalah jumlah rumpun per satuan luas (ha), rata-rata banyaknya batang sulur per rumpun dan diameternya pada setiap lokasi. Selain itu juga dihitung sebaran ketak pada masing-masing lokasi. Cakupan sebaran dihitung berdasarkan jumlah titik atau petak ditemukannya jenis rumput ketak dari seluruh petak yang dibuat pada suatu lokasi.

3. Analisis kondisi tempat tumbuh. Data karakteristik tempat tumbuh, dianalisis secara deskriptif kuantitatif maupun kualitatif. Variabel yang dideskripsikan adalah topografi, kemiringan lahan, kondisi batuan baik batuan singkapan maupun batuan permukaan, ketinggian tempat, iklim (tipe iklim, curah hujan, temperatur tanah dan kelembaban udara), sifat kimia dan fisika tanah yang terdiri dari tekstur, bahan organik, $\mathrm{pH}$ tanah, KTK, unsur makro, dan salinitas.

4. Analisis INP. Untuk menentukan INP, terlebih dahulu data vegetasi dianalisis dengan mencari kerapatan relatif (KR)dan frekuensi relatif (FR), dengan menggunakan persamaan, INP $=\mathrm{KR}+$ FR (Indriyanto, 2009).

5. Analisis Pricipal Component Analysis (PCA). PCA adalah teknik statistik yang diaplikasikan untuk satu kumpulan variabel untuk menemukan variabel mana dalam kumpulan tersebut yang berhubungan dengan lainnya. Analisis PCA (analisis komponen utama) yaitu kelerengan, ketinggian tempat, kelembaban, suhu, dan penyinaran. Analisis ini dilakukan untuk mengetahui seberapa jauh faktorfaktor lingkungan berpengaruh terhadap keberadaan rumput ketak.

6. Analisis asosiasi. Analisis asosiasi untuk mengetahui asosiasi (kekerabatan) rumput ketak dengan jenis lainnya. Untuk mengetahui bahwa dua jenis berasosiasi, maka digunakan metode tabel contingency $2 \times 2 \mathrm{~m}$, kemudian diuji dengan Chi-square $\left(\chi^{2}\right)$. 


$$
\begin{aligned}
x^{2} & =\frac{[a-E(a)]^{2}}{E(a)}+\frac{[b-E(b)]^{2}}{E(b)}+\frac{[c-E(c)]^{2}}{E(c)}+\frac{[d-E(d)]^{2}}{E(d)} \\
& =\frac{(a+b) x(a+c)}{n}{ }_{m} E(b)=\frac{(a+b) x(b+d)}{n} \\
& =\frac{(a+c) x(c+d)}{n}{ }_{\ldots .} E(d)=\frac{(b+d) x(c+d)}{n}
\end{aligned}
$$

Indeks Jaccard $=\frac{a}{(a+b+c)}$

Keterangan (Remarks):

$\mathrm{a}=$ Jumlah sampling dengan kedua jenis hadir (Number of sampling with both types present);

$\mathrm{b}=$ Jenis A hadir dan B tidak hadir (Type A is present and $B$ is absent);

$\mathrm{c}=$ Jenis A tidak hadir dan B hadir (Type A is absent and $B$ is present);

$\mathrm{d}=$ Jenis A dan B tidak hadir (Type A and B

are absent);

$\mathrm{n}=$ Jumlah sampling keseluruhan (Total sampling amount);

Tipe asosiasi positif jika nilai a $>\mathrm{E}$ (a) dan negatif jika a $<E(a)$. Berasosiasi atau tidak ditentukan berdasarkan nilai $\chi^{2}$, jika nilai $\chi^{2}$-hitung $<\chi^{2}$-tabel, maka kedua jenis yang diuji berasosiasi. Uji indeks Jaccard menyatakan tingkatan asosiasi. Semakin mendekati nilai 1 , maka asosiasi semakin maksimum (Silalahi, 2016)

\section{HASIL DAN PEMBAHASAN}

\section{A. Hasil}

\section{Sebaran dan potensi rumput ketak}

Hasil survey di KPHL Rinjani Barat,rumput ketak ditemukan di Kawasan Hutan Malimbu, Lombok Utara dan Kawasan Pusuk, Kabupaten Lombok Barat sedangkan di KPHL Rinjani Timur ditemukan di Kawasan Hutan Langlang Mentareng dan Obel-obel yang berada di Kecamatan Sambelia, Kabupaten Lombok Timur. Lokasi ditemukannya rumput ketak terlihat pada Gambar 1 sedangkan potensi

rumput ketak pada setiap lokasi disajikan pada Tabel 1.

Pada Tabel 1 diketahui bahwa cakupan sebaran sampai $30 \%$ dan rata-rata diameter sulurnya kurang dari $2 \mathrm{~mm}$. Potensi ketak yang ditemukan relatif rendah, yaitu rata-rata 443 rumpun/ha jumlah sulur adalah 5,2 batang sulur/rumpun, dan rata-rata jumlah sulur yang siap panen di KPHL Rinjani Barat 3 batang/rumpun, sedangkan di KPHL Rinjani Timur hampir tidak ada sulur yang dipanen.

\section{Kondisi tempat tumbuh ketak}

Di KPHL Rinjani Timur ketak ditemukan pada ketinggian 49-305 mdpl, topografi berupa perbukitan terjal,batuan singkapan sebesar $10 \%$, dan batuan permukaan mencapai 5\%. Di KPHL Rinjani Barat ditemukan pada ketinggian 93-366 mdpl, tidak ditemukan adanya batuan permukaan, dan singkapan pada habitat ketak. Besarnya persentase batuan singkapan mengindikasikan adanya proses erosi pada wilayah tersebut. Di kedua lokasi tersebut kondisi lerengnya mulai landai sampai curam. Iklim di lokasi penelitian termasuk tipe iklim C-E dengan curah hujan 935-1.511 $\mathrm{mm} / \mathrm{tahun}$ temperatur udara $24-32^{\circ} \mathrm{C}$, kelembaban udara 50-88\%. Intensitas cahaya di KPHL Rinjani Barat berada pada kisaran1203.872 lux, sedangkan di KPHL Rinjani Timur antara 178-1.910 lux.

Tempat tumbuh rumput ketak dikedua lokasi mempunyai struktur granuler dan tekstur yang didominasi oleh fraksi pasir. Fraksi pasir di KPHL Rinjani Barat mencapai lebih dari $70 \%$ sedangkan di Rinjani Timur mencapai lebih dari $60 \%$. Sifat kimia tanah lokasi penelitian yaitu $\mathrm{pH}$ agak masam, C-organik sedang-tinggi, KTK rendah-sedang, unsur hara N sedang, $\mathrm{P}$ sedang, $\mathrm{K}$ sangat tinggi, $\mathrm{Ca}$ tinggi, dan $\mathrm{Mg}$ rendah. Unsur hara mikro dalam kondisi rendah. Data hasil analisis disajikan pada Tabel 2.

\section{Indeks Nilai Penting (INP)}

Jumlah jenis yang ditemukan pada habitat rumput ketak di KPHL Rinjani Barat adalah 190 jenis. Hasil analisis INP 
diketahui bahwa jenis yang mempunyai tingkat dominansi tertinggi di habitat rumput ketak di KPHL Rinjani Barat adalah jenis mahoni (S. macrophylla) sebesar $17,40 \%$. Lokasi penelitian diketahui merupakan habitat alami mahoni. Selanjutnya dominansi diikuti rumput ketak sebesar 17,31\% (Tabel 3).

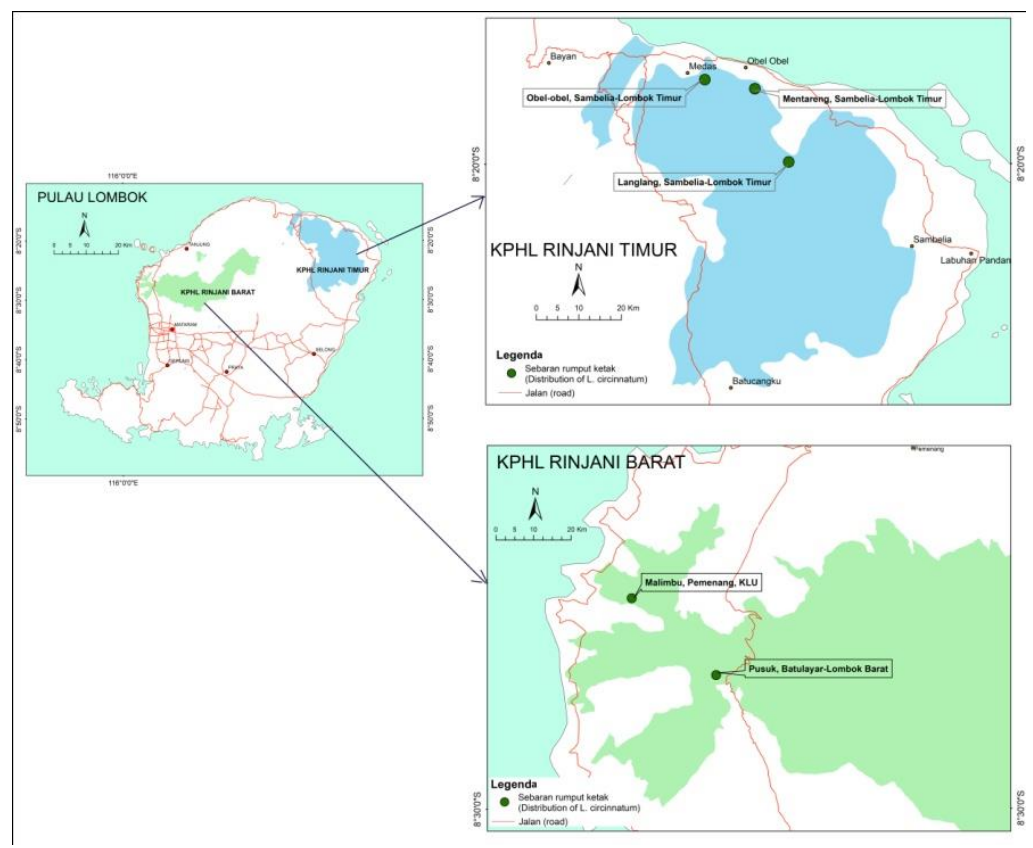

Gambar(Figure) 1.Peta sebaran rumput ketak di KPHL Rinjani Barat dan Timur (Distribution of L. circinnatum in the West and East Rinjani PFMU/Protected Forest Management Unit)

Tabel (Table) 1. Potensi rumput ketak di Lombok (Potency of $\underline{\text { L. circinnatum in Lombok) }}$

\begin{tabular}{|c|c|c|c|c|c|}
\hline \multirow[t]{2}{*}{ No. } & \multirow[t]{2}{*}{ Lokasi (Location) } & \multirow{2}{*}{$\begin{array}{c}\text { Sebaran } \\
\text { (Distribution) } \\
(\%)\end{array}$} & $\begin{array}{l}\text { Potensi } \\
\text { (Potency) }\end{array}$ & \multirow[t]{2}{*}{$\begin{array}{c}\text { Jumlah } \\
\text { sulur/rumpun } \\
\text { (Number of } \\
\text { tendrils/clump })\end{array}$} & \multirow[t]{2}{*}{$\begin{array}{l}\text { Diameter } \\
\text { sulur } \\
\text { (Diameter } \\
\text { oftendrils } \\
(\mathrm{mm})\end{array}$} \\
\hline & & & $\begin{array}{l}\text { (Rumpun/ha } \\
\text { (Clumps/ha) }\end{array}$ & & \\
\hline 1 & Malimbu, Pemenang KLU & 45,65 & 561 & 6 & 2,73 \\
\hline 2 & Pusuk, Batulayar Lobar & 66,04 & 894 & 10 & 2,48 \\
\hline 3 & Langlang, Sambelia Lotim & 16,61 & 475 & 4 & 1,43 \\
\hline 4 & $\begin{array}{l}\text { Obel-Obel, Sambelia } \\
\text { Lotim }\end{array}$ & 15,78 & 187 & 3 & 1,73 \\
\hline 5 & $\begin{array}{l}\text { Mentareng, Sambelia } \\
\text { Lotim }\end{array}$ & 10,64 & 100 & 3 & 1,42 \\
\hline & Rata-rata (Average) & 30,94 & 443 & 5,2 & 1.96 \\
\hline
\end{tabular}


Tabel (Table) 2. Sifat kimia tanah di KPHL Rinjani Timurdan KPHL Rinjani Barat (Soil chemicalproperties in East Rinjani PFMUand West Rinjani PFMU)

\begin{tabular}{|c|c|c|c|c|c|c|c|c|c|}
\hline \multirow[t]{2}{*}{$\begin{array}{c}\text { Parameter } \\
\text { (Parameters) }\end{array}$} & \multicolumn{2}{|c|}{$\begin{array}{l}\text { Maksimum } \\
\text { (Maximum) }\end{array}$} & \multicolumn{2}{|c|}{$\begin{array}{l}\text { Minimum } \\
\text { (Minimum) }\end{array}$} & \multicolumn{2}{|c|}{$\begin{array}{l}\text { Rata-rata } \\
\text { (Average) }\end{array}$} & \multicolumn{3}{|c|}{ Kategori (Category) } \\
\hline & RT & RB & RT & RB & RT & $\mathrm{RB}$ & RT & \multicolumn{2}{|l|}{$\mathrm{RB}$} \\
\hline$\overline{\mathrm{pH}}$ & 6,90 & 6,59 & 6,17 & 6,17 & 6,53 & \multicolumn{2}{|c|}{$\begin{array}{l}\text { 6,42 Agak masam (Rather } \\
\text { sour) }\end{array}$} & $\begin{array}{l}\text { Agak masam } \\
\text { sour) }\end{array}$ & her \\
\hline C-organik (\%) & 6,21 & 3,56 & 3,18 & 1,90 & 4,24 & 2,77 & 7 Tinggi $(H i g h)$ & Sedang (Mediu & \\
\hline $\mathrm{KTK}(\mathrm{cmol} / \mathrm{g})$ & 28,31 & 20,04 & 10,45 & 1,74 & 20,02 & 10,05 & 5 Sedang (Medium) & Rendah (Low) & \\
\hline \multicolumn{10}{|c|}{ Unsur makro (Macro elements): } \\
\hline $\mathrm{N}(\%)$ & 0,43 & 0,32 & 0,31 & 0,17 & 0,36 & 0,26 & 6 Sedang (Medium) & Sedang (Mediu & \\
\hline $\mathrm{P}(\mathrm{ppm})$ & 39,53 & 78,54 & 0,26 & 1,14 & 11,20 & 15,55 & 5 Sedan & Sed & \\
\hline $\mathrm{K}(\mathrm{ppm})$ & 80,79 & 94,41 & 45,04 & 40,57 & 70,15 & & $\begin{array}{l}5 \text { Sangat tinggi (Very } \\
\text { high) }\end{array}$ & Sangat tinggi ( & ery high) \\
\hline $\mathrm{Ca}(\mathrm{ppm})$ & 732,9 & 757,2 & 344,1 & 245,2 & 533,8 & 451,8 & 8 Tinggi/ High & Tin & \\
\hline $\mathrm{Mg}(\mathrm{ppm})$ & 5,94 & 6,43 & 3,57 & 3,31 & 4,86 & 4,88 & $8 \mathrm{Re}$ & & \\
\hline $\mathrm{S}(\mathrm{ppm})$ & 16,76 & 18,60 & 2,72 & 0,26 & 7,14 & 5,68 & & I. & \\
\hline \multicolumn{10}{|c|}{ Unsur mikro (Micro elements): } \\
\hline $\mathrm{Fe}(\mathrm{ppm})$ & 2,88 & 2,54 & 1,32 & 1,54 & 1,91 & \multicolumn{2}{|c|}{$\begin{array}{l}\text { 2,15 Sangat rendah (Very } \\
\text { low) }\end{array}$} & \multicolumn{2}{|c|}{$\begin{array}{l}\text { Sangat rendah (Very } \\
\text { low) }\end{array}$} \\
\hline $\mathrm{Mn}(\mathrm{ppm})$ & 3,33 & 3,45 & 1,31 & 0,30 & 1,92 & 1,55 & 5 Rendah (Low) & Rendah (Low) & \\
\hline $\mathrm{Cu}(\mathrm{ppm})$ & 4,88 & 5,83 & 2,51 & 2,37 & 3,76 & 4,03 & $3 \mathrm{Cul}$ & $\mathrm{Cuk}$ & \\
\hline $\mathrm{Zn}(\mathrm{ppm})$ & 1,11 & 0,97 & 0,28 & 0,50 & 0,64 & 0,85 & 5 Marginal (Marginal) & Marginal (Mar\& & inal) \\
\hline \multicolumn{10}{|c|}{$\begin{array}{l}\text { Sumber (Source): Hasil analisis Laboratorium Tanah BPPT Mataram } 2016 \text { (Analysis result of soil laboratorium of BPPT } \\
\text { Mataramon 2016). }\end{array}$} \\
\hline \multicolumn{10}{|c|}{$\begin{aligned} \text { Keterangan }(\text { Remarks): } & \text { RT = KPHL Rinjani Timur (East Rinjani PFMU), RB = KPHL Rinjani Barat (West Rinjan } \\
& P F M U)\end{aligned}$} \\
\hline \multicolumn{10}{|c|}{$\begin{array}{c}\text { Tabel (Table) 4. Nilai eigenvectors pada analisis PCA (Value of eigenvectors in PCA } \\
\text { analysis) }\end{array}$} \\
\hline \multicolumn{3}{|c|}{$\begin{array}{ll}\text { No. } & \text { KPHL Rinjani } \\
& \text { Barat (West Rinjani } \\
& U P F M) \\
\end{array}$} & \multicolumn{2}{|c|}{$\mathrm{F} 1$} & \multicolumn{2}{|l|}{$\mathrm{F} 2$} & $\begin{array}{ll}\text { No. } & \text { KPHL Rinjani } \\
& \text { Timur (East } \\
& \text { Rinjani UPFM) } \\
\end{array}$ & $\mathrm{F} 1$ & $\mathrm{~F} 2$ \\
\hline Lerer & $\mathrm{g}($ Slop & & & 038 & 0,6035 & & Lereng (Slope) & 0,3524 & 0,7853 \\
\hline Suhu & (Tempe & rature) & & 354 & $-0,300$ & & $\begin{array}{l}\text { 2. } \begin{array}{l}\text { Ketinggian } \\
(\text { Height })\end{array}\end{array}$ & 0,7581 & 0,0794 \\
\hline $\begin{array}{l}\text { 3. } \\
\text { Keler }\end{array}$ & $\begin{array}{l}\text { lbaban } \\
\text { idity) }\end{array}$ & & $-0,3$ & 3586 & 0,5729 & & $\begin{array}{l}\text { Penyinaran } \\
\text { (Radiation) }\end{array}$ & $-0,5487$ & 0,6141 \\
\hline Ketin & ggian & & $-0,4$ & 4052 & 0,16 & & & & \\
\hline $\begin{array}{l}\text { Peny } \\
\text { Radi }\end{array}$ & $\begin{array}{l}\text { naran } \\
\text { ation }\end{array}$ & & & 729 & 0,4360 & & & & \\
\hline
\end{tabular}

4. Pola distribusi, asosiasi, dan analisis PCA

Melalui analisis PCA (Principal Component Analysis) diketahui bahwa faktor-faktor lingkungan berupa lereng, ketinggian tempat, penyinaran, suhu, dan kelembaban mempengaruhi keberadaan ketak di habitatnya. Nilai eigenvectors pada analisis PCA disajikan pada Tabel 4.
Di lokasi KPHL Rinjani Barat,selain rumput ketak terdapat 186 jenis lain. Jenis rumput ketak mempunyai asosiasi positif dengan sebagian besar jenis lainnya. Jenisjenis dengan asosiasi tertinggi ditunjukkan oleh nilai indeks jaccard yang lebih besar, yaitu jenis tapen (Gmelina sp.), pakis ( $C$. rumphii), mahoni ( $S$. macrophylla), dan kumbi (T. sphaerocarpa). Pola distribusi dan asosisasi jenis di KPHL Rinjani Barat 
terlihat pada Tabel 5, sedangkan pola distribusi dan asosisasi jenis di KPHL Rinjani Timur terlihat pada Tabel 6.

Untuk lokasi KPHL Rinjani Timur, rumput ketak berasosiasi positif dengan sebagian besar jenis yang ditemui di lokasi tersebut (Tabel 6). Jumlah jenis lain yang ditemui pada lokasi ini adalah sebanyak 67 jenis. Adapun jenis dengan nilai indeks jaccard relatif besar adalah jenis elok (Aglaia orgentea), jambu-jambuan (Eugenia sp.), rike (Drypetessp.), dan kukun (Sonneratia ovata).

Tabel (Table) 5. Pola distribusi dan asosiasi 10 jenis dengan $\mathrm{X}^{2}$ tertinggi di KPHL Rinjani Barat (Distribution pattern and association of 10 species with the highest $X^{2}$ in West Rinjani PFMU)

\begin{tabular}{cllcccc}
\hline No & $\begin{array}{c}\text { Jenis } \\
\text { (Species) }\end{array}$ & $\begin{array}{c}\text { Nama botani } \\
\text { (Botany name) }\end{array}$ & $\mathrm{X}^{2}$ & $\begin{array}{c}\text { Asosiasi } \\
\text { (Association) }\end{array}$ & $\begin{array}{c}\text { Tipe asosiasi } \\
\text { (Type of } \\
\text { association) }\end{array}$ & $\begin{array}{c}\text { Indeks Jaccard } \\
\text { (Index of } \\
\text { Jaccard) }\end{array}$ \\
\hline 1 & Tapen & Gmelina sp. & 84,04 & Ya/Yes & + & 0,51 \\
2 & Pakis & C. rumphii & 76,73 & Ya/Yes & + & 0,48 \\
3 & Mahoni & S. macrophylla & 53,23 & Ya/Yes & + & 0,36 \\
4 & Kumbi & T. sphaerocarpa & 49,69 & Ya/Yes & + & 0,34 \\
5 & Kirinyuh & C. odorata & 48,53 & Ya/Yes & + & 0,34 \\
6 & Badung & G. parviflora & 42,89 & Ya/Yes & + & 0,30 \\
7 & Jukut & E. polyantha & 41,79 & Ya/Yes & + & 0,30 \\
8 & Talas & L. indica & 40,70 & Ya/Yes & + & 0,29 \\
9 & Aren & A. pinnata & 37,49 & Ya/Yes & + & 0,27 \\
10 & Kenerongan Harpulia sp. & 37,49 & Ya/Yes & + & 0,27 \\
\hline
\end{tabular}

Tabel (Table) 6. Pola distribusi dan asosiasi 15 jenis dengan $\mathrm{X}^{2}$ tertinggi di KPHL Rinjani Timur (Distribution pattern and association of 15 species with the highest $X^{2}$ in East Rinjani PFMU)

\begin{tabular}{|c|c|c|c|c|c|c|}
\hline No & $\begin{array}{c}\text { Nama lokal } \\
(\text { Local name }))\end{array}$ & $\begin{array}{l}\text { Nama botani } \\
\text { (Botany name) }\end{array}$ & $X^{2}$ & $\begin{array}{c}\text { Asosiasi } \\
\text { (Association) }\end{array}$ & $\begin{array}{l}\text { Tipe asosiasi } \\
\text { (Type of } \\
\text { association) }\end{array}$ & $\begin{array}{c}\text { Indeks } \\
\text { Jaccard } \\
\text { (Index of } \\
\text { Jaccard) }\end{array}$ \\
\hline 1 & Elok & Aglaia orgentea & 162,83 & $\mathrm{Ya} / Y e s$ & + & 0,57 \\
\hline 2 & Jambu-jambuan & Eugenia sp. & 111,35 & $\mathrm{Ya} / Y e s$ & + & 0,40 \\
\hline 3 & Rike & Drypetes sp. & 111,35 & $\mathrm{Ya} / Y e s$ & + & 0,40 \\
\hline 4 & Kukun & Sonneratia ovata & 97,97 & $\mathrm{Ya} / Y e s$ & + & 0,36 \\
\hline 5 & Ketemek & Pentace sp. & 76,28 & $\mathrm{Ya} / Y e s$ & + & 0,28 \\
\hline 6 & Lempedek & $\begin{array}{l}\text { Artocarpus } \\
\text { champeden }\end{array}$ & 76,28 & $\mathrm{Ya} / Y e s$ & + & 0,28 \\
\hline 7 & Juwet & $\begin{array}{l}\text { Lepisanthes } \\
\text { palawanica }\end{array}$ & 63,60 & $\mathrm{Ya} / Y e s$ & + & 0,24 \\
\hline 8 & Jerukan & Atalantia trimera & 59,43 & $\mathrm{Ya} / Y e s$ & + & 0,22 \\
\hline 9 & Kelak/sangitan & $\begin{array}{l}\text { Sambucus } \\
\text { javanica }\end{array}$ & 59,43 & $\mathrm{Ya} / Y e s$ & + & 0,22 \\
\hline 10 & Kesambi & $\begin{array}{l}\text { Schleichera } \\
\text { oleosa }\end{array}$ & 59,43 & $\mathrm{Ya} / Y e s$ & + & 0,22 \\
\hline
\end{tabular}


Tabel (Table) 6. Lanjutan (Continuation)

\begin{tabular}{|c|c|c|c|c|c|}
\hline 11 Kirinyuh & C. odorata & 59,43 & $\mathrm{Ya} / Y e s$ & + & 0,22 \\
\hline 12 Akar bakti & $\begin{array}{l}\text { Ligustrum } \\
\text { obtusifolium }\end{array}$ & 47,08 & $\mathrm{Ya} / Y e s$ & + & 0,18 \\
\hline 13 Lempinyo & Aglaia sp. & 43,02 & $\mathrm{Ya} / Y e s$ & + & 0,16 \\
\hline 14 Keleang & $\begin{array}{l}\text { Pterospermum } \\
\text { diversifolium }\end{array}$ & 38,98 & $\mathrm{Ya} / Y e s$ & + & 0,15 \\
\hline 15 Ketimus & Ipomea batatas & 38,98 & $\mathrm{Ya} / Y e s$ & + & 0,15 \\
\hline
\end{tabular}

\section{A. Pembahasan}

Potensi rumput ketak di KPHL Rinjani Timur relatif rendah, baik jumlah rumpun per hektar maupun jumlah sulur per rumpunnya (Tabel 1). Rata-rata jumlah sulur 5,2 sulur/rumpun dan batang sulur yang siap dipanen hampir tidak ada. Sementara potensi ketak di KPHL Rinjani Barat, hanya tersedia sulur yang siap dipanen rata-rata 3 batang/rumpun. Itupun rata-rata ukuran diameter batangnya yang relatif kecil (diameter ruas pertama $\geq 3$ $\mathrm{mm}$ ), untuk pemenuhan bahan baku produk anyaman ukuran kecil seperti alas gelas, tas kecil, dan bukan sebagai bahan baku untuk tulang kerangka produk kerajinan (Hasan \& Susila, 2018; Susila \& Setyayudi, 2017). Untuk kebutuhan bahan baku ketak dengan ukuran batang sulur yang lebih besar, pengrajin di Lombok mendatangkan dari luar Lombok seperti Kalimantan, Flores, Jawa, Sulawesi, dan Sumbawa. Kebutuhan bahan baku tiap tahun untuk pengrajin ketak di Lombok belum bisa diprediksi karena belum adanya data jumlah produksi dan siklus panen dari tanaman ketak. Menurut informasi masyarakat setempat, pemanenanburuan rumput ketak di kawasan Obel-obel dan sekitarnya sudah dilarang sejak 5 tahun yang lalu. Padakondisi tersebut, seharusnya potensi rumput ketak besar, namun saat ini pasokan ketak ke pengrajin masih rendah. Hal ini diduga akibat perburuan rumput ketak masih terus berlangsung. Seperti di Pusuk dan Malimbu KPHL Rinjani Barat, masyarakat mengakui bahwa banyak orang memungut rumput ketak di hutan alam karena lokasi pengrajin dekat dengan habitat rumput ketak. Rendahnya pasokan atau potensi ketak di KPHL Rinjani Timur, diduga akibat perbedaan cara memanen tanaman ketak sebelumnya dengan pemanenan di KPHL Rinjani Barat, seperti dengan cara dipangkas batang sulur pada setiap rumpun atau dengan cara dicabut rumpun/sulur semuanya. Pengalaman yang sering dilihat pada rumpun ketak di Kawasan Pusuk, petani hanya memangkas batang sulur yang cocok untuk bahan baku anyaman. Dari bekas pangkasan tersebut akan tumbuh tunas-tunas baru sebagai calon bahan baku. Berbeda dengan cara dicabut sekaligus, kecil peluangnya tumbuh tanaman baru disekitar cabutan. Kondisi tapak lingkungan lokasi penelitian, relatif tidak jauh berbeda, bahkan hasil analisis tanah sebelumnya ternyata di KPHL Rinjani Timur sedikit lebih baik (fraksi pasirnya 60\%). Aksesibilitas lokasi yang di KPHL Rinjani Timur lebih sulit dan sangat jauh dari sentra pengrajin ketak di Lombok Tengah.

Menurut karakternya, rumput ketak memiliki pertumbuhan yang relatif lambat serta rentan terhadap perubahan lingkungan yaitu peka terhadap perubahan cuaca. Hal ini sesuai dengan hasil penelitian Effendi \& Sebastian (2015) bahwa pertumbuhan ketak sangat lambat. Dari hasil pengamatan di lapangan bahwa permudaan alam rumput ketak masih mengandalkan tumbuhnya tunas-tunas baru berupa rimpang dari setiap rumpun. Untuk meningkatkan budidaya rumput ketak bisa dilakukan melalui penyiapan bibit dengan spora. Kultivasi ex-vitro lebih disarankan karena lebih mudah dan spora tumbuh lebih cepat dibandingkan dengan in-vitro (Dwiyani, 2016). 
Untuk mendukung keberhasilan pertumbuhan rumput ketak, maka pohon pemanjat menjadi penting untuk diketahui. Dari hasil pengamatan di lapangan ternyata pohon pemanjat untuk rumput ketak bisa segala jenis pohon yang ada di sekitarnya. Hal ini sesuai dengan hasil penelitian Wahyuningsih, Faridah, \& Budiadi (2017) bahwa keberadaan pohon pemanjat sangat diperlukan untuk mendukung pertumbuhan tanaman ketak. Wahyuningsih, Faridah \& Syahbudin, (2018a) menyatakan bawa jenis tanaman rambatan bagi ketak dapat berbeda berdasarkan ketinggian tempat tumbuh ketak. Pada ketinggian 0-250 m dpl, tanaman rambatannya adalah Arenga pinnata, Lansium domesticum, dan liana; pada ketinggian 250-500 m dpl tanaman rambatannya adalah Hibiscus tiliaceus, Tabernaemontana sp., dan Gyrinops verstegii. Sedangkan pada ketinggian 500$750 \mathrm{~m}$ dpl, ketak merambat pada tanaman Coffea canephora, Arenga pinnata, dan liana. Dengan demikian, rumput ketak tidak memerlukan pohon perambat dari jenis tertentu, tetapi semua jenis pohon yang ada di sekitar rumput ketak bisa menjadi pohon rambatan.

Rumput ketak mampu tumbuh baik pada ketinggian 49-366 m dpl, topografi landai sampai curam, tipe iklim C-E berdasarkan klasifikasi Schmidt dan Ferguson dengan curah hujan antara 935$1.511 \mathrm{~mm} /$ tahun, temperatur udara 24$32^{\circ} \mathrm{C}$, kelembaban antara 50-88\%. Intensitas cahaya berkisar 120-3.872 lux. Kondisi tanah tempat tumbuh rumput ketak berstruktur granuler dengan tekstur tanah lebih banyak fraksi pasir (fraksi pasir antara 60-70\%) (Tabel 2). Penyebaran ketak di kawasan Gunung Pusuk mencakup kawasan dengan ketinggian 100-900 m dpl dengan kerapatan paling tinggi pada ketinggian $900 \mathrm{~m} \mathrm{dpl}$, sedangkan sebaran yang tertinggi terdapat pada ketinggian 600 m dpl (Darma \& Arinasa, 2009).

Tempat tumbuh ketak baik di KPHL Rinjani Barat maupun Rinjani Timur mempunyai $\mathrm{pH}$ tanah antara agak asam sampai mendekati netral. Nilai $\mathrm{pH}$ tanah netral akan memudahkan tanaman dalam menyerap unsur hara karena unsur hara mudah larut dalam air. Kondisi tanah di KPHL Rinjani Barat berupa kandungan C-organik sedang dan KTK rendah sedangkan di KPHL Rinjani Timur Corganik tinggi dan KTK sedang. KTK merupakan sifat kimia yang erat hubungannya dengan kesuburan tanah sedangkan kandungan bahan organik tanah akan menentukan mudah tidaknya tanah dalam menyimpan air dan unsur hara yang dibutuhkan oleh tanaman.

Dalam tanah, unsur nitrogen $(\mathrm{N})$ diperlukan terutama untuk pertumbuhan vegetatif. Unsur ini dipasok terutama dari bahan organik tanah sehingga keberadaan bahan organik tanah umumnya akan berkorelasi positif dengan kandungan unsur N. Pemberian pupuk urea sebanyak $300 \mathrm{~g} /$ tanaman dapat meningkatkan jumlah sulur tanaman ketak (Dwiyani \& Hestin, 2012). Untuk unsur fosfor (P), di kedua lokasi penelitian ditemukan dalam jumlah yang sedang.Unsur $\mathrm{P}$ digunakan terutama untuk pembelahan sel dan perkembangan generatif tanaman. Kekurangan unsur ini akan mengakibatkan tanaman menjadi kerdil, perubahan warna daun, dan terganggunya perkembangan buah, namun di lapangan terlihat tanaman ketak dapat tumbuh baik meskipun dengan kandungan unsur $\mathrm{P}$ dalam jumlah sedang.

Kalsium (Ca), mempunyai peran dalam pertumbuhan sel termasuk menguatkan, mengatur daya tembus, serta merawat dinding sel. Selain itu berperan juga dalam proses pembelahan dan perpanjangan sel, dan mengatur distribusi hasil fotosintesis. Di kedua lokasi penelitian menunjukkan kondisi yang sama yaitu mempunyai kandungan $\mathrm{Ca}$ yang cukup tinggi. Berdasarkan sifat fisik tanah tempat tumbuh ketak baik di KPHL Rinjani Barat maupun Rinjani Timur 
mempunyai laju resapan air yang baik, kapasitas menyimpan airnya rendah, kandungan unsur hara cenderung rendah, namun cukup baik untuk sistem perakaran.

Indeks Nilai Penting (INP) dapat digunakan sebagai salah satu parameter penentuan pentingnya suatu jenis dan penentuan jenis prioritas untuk konservasi. Untuk lokasi KPHL Rinjani Timur, jenis dengan nilai INP tertinggi adalah jenis elok (Aglaia orgentea) (29,7\%), sedangkan rumput ketak mempunyai nilai INP $28,29 \%$. Jumlah jenis lain yang ditemukan di KPHL Rinjani Timur adalah 68 jenis. Keragaman jenis di KPHL Rinjani Timur lebih rendah daripada KPHL Rinjani Barat. Tanaman rumput ketak, baik di KPHL Rinjani Barat maupun KPHL Rinjani Timur mempunyai INP relatif besar.

Pola distribusi spasial rumput ketak dalam komunitasnya mengikuti pola distribusi mengelompok, artinya keberadaan individu pada suatu titik akan meningkatkan peluang adanya individu lain pada titik yang lain di sekitarnya. Hal ini sesuai dengan nilai Kepangkatan Taylor yang lebih dari 1. Hasil perhitungan nilai kepangkatan Taylor pada lokasi penelitian $>1$. Di lokasi KPHL Rinjani Barat sebesar 4,23 sedangkan di KPHL Rinjani Timur adalah 4,95, hal ini menggambarkan bahwa tanaman ketak pada lokasi penelitian secara umum penyebarannya bersifat mengelompok. Pola distribusi ini dapat disebabkan oleh berbagai faktor diantaranya perbedaan kondisi tanah, sumberdaya, dan kompetisi. Selain itu juga dapat disebabkan oleh kecenderungan reproduksi tumbuhan dimana tumbuhan bereproduksi dengan biji yang jatuh atau rimpang yang menghasilkan anakan vegetatif di dekat induknya.

Jenis ketak berasosiasi positif dengan jenis lainnya berarti keberadaan kedua jenis tersebut pada suatu tempat yang berdekatan sering ditemukan. Sementara nilai index jaccard menunjukkan kualitas asosiasinya, jika keberadaan rumput ketak pada suatu tempat selalu ditemukan jenis tertentu maka nilai index jaccard sangat tinggi (mendekati nilai 1) dan sebaliknya jenis ketak tidak ditemukan apabila jenis tertentu tersebut ditemukan, nilai index jaccard sangat rendah (mendekati nilai 0).

Keberadaan jenis pada suatu wilayah sangat dipengaruhi oleh kondisi lingkungannya, termasuk kondisi fisik. Hal ini sejalan dengan Wahyuningsih, Faridah, \& Syahbudin (2018b) yang menyatakan bahwa pertumbuhan ketak sangat dipengaruhi oleh faktor genetik dan lingkungan. Hasil analisis PCA menunjukkan faktor lingkungan di $\mathrm{KPH}$ Rinjani Barat yaitu kemiringan lereng, kelembaban, dan intensitas penyinaran mempunyai pengaruh yang signifikan (Tabel 6). Hal ini ditunjukkan dengan besarnya nilai eigenvectors dari variabel tersebut (F2). Nilai eigenvectors adalah koefisien kombinasi linier variabel yang menyusun sebuah principal component pada analisis PCA. Hasil analisis PCA dapat diketahui bahwa faktor lingkungan berpengaruh terhadap keberadaan ketak di habitatnya.Pada lokasi KPHL Rinjani Timur ternyata faktor lereng dan intensitas cahaya sebagai faktor yang berpengaruh, namun faktor suhu dan kelembaban tidak teridentifikasi.Informasi ini penting sebagai dasar dalam implementasi budidaya jenis rumput ketak.

\section{KESIMPULAN DAN SARAN}

\section{A. Kesimpulan}

Potensi dan kualitas ketak yang ditemukan di KPHL Rinjani Timur dan KPHL Rinjani Barat termasuk rendah. Potensi rumput ketak di Lombok relatif rendah dengan jumlah sulur 443 rumpun/ha, jumlah sulur 5,2 batang sulur/rumpun, dan jumlah sulur yang siap panen 3 batang/rumpun. Rumput ketak mempunyai peran penting dalam ekosistem di KPHL Rinjani Timur dan KPHL Rinjani 
Barat, hal ini ditunjukkan dengan nilai INP ketak yang cukup tinggi. Keberadaan ketak sangat dipengaruhi oleh kondisi lingkunganyaitu faktor kemiringan lahan, ketinggian tempat, penyinaran, suhu, dan kelembaban. Pola distribusi spasial jenis rumput ketak di habitat alaminya mengikuti pola distribusi mengelompok, ditemukan 186 jenis laindi KPHL Rinjani Barat. Jenis-jenis yang berasosiasi positif secara berurutan yaitu jenis tapen, pakis, mahoni, dan kumbi. Di KPHL Rinjani Timur ditemukan jenis lain 67 jenis dan jenis yang berasosiasi positif adalah elok jambu-jambuan, rike, dan kukun. Ketak memiliki variasi tempat tumbuh yang tinggi, struktur tanah di habitat ketak yaitu granuler, tekstur didominasi fraksi pasir, $\mathrm{pH}$ tanah antara agak asam sampai netral, dan tingkat kesuburannya termasuk sedang.

\section{A. Saran}

Potensi rumput ketak di alam semakin menurun. Untuk itu perlu dilakukan peningkatan pemahaman petani atau pengrajin untuk melakukan kegiatan budidaya rumput ketak untuk mendukung ketersediaan bahan baku sehingga potensi di alam dapat diringkatkan populasinya.

\section{UCAPAN TERIMA KASIH}

Penelitian ini dibiayai DIPA tahun 2016 Balai Penelitian dan Pengembangan Teknologi Hasil Hutan Bukan Kayu Mataram. Penulis menyampaikan ucapan terima kasih kepada Kepala dan staf KPHL Rinjani Barat dan KPHL Rinjani Timur yang telah membantu pelaksanaan penelitian di lapangan.

\section{DAFTAR PUSTAKA}

Aji. I, Sutriono, R., \& Taufik. M. (2012). Pengaruh Intensitas Cahaya dan Dosis Pupuk Organik Cair NASA terhadap Pertumbuhan Bibit Ketak (Lygodium circinnatum (Burn. F) Swartz)
Cabutan. Media Bina Ilmiah, 9(7), 3741.

Darma, \& Arinasa, I.D.P. (2009). Konservasi Flora Indonesia dalam Mengatasi Pemanasan Global (p. 658). Indonesian Institute of Sciences (LIPI) UPT Balai Konservasi Tumbuhan Kebun Raya "Eka Karya" Bali*.

Dwiyani, R. (2016). In vitro and ex vitro Propation of a wild-extinct fern Lygodium circinnatum (Burn. F.) Sw. Grown in Bali. Jurnal Bumi Lestari, 16(2), 131-138.

Dwiyani, R., \& Hestin, Y. (2012). Respon sporofit paku ata (Lygodium circinnatum (Burn. F.) Swartz) terhadap pemberian pupuk urea. Jurnal Agrotrop, 2(1), 63-66.

Effendi, R., \& Sebastian, G.M. (2015). Buku Petunjuk Pembibitan Rumput Ketak (Lygodium circinnatum) melalui spora. Proyek Kerjasama Word Agroforestry Centre/ICRAF, Australian Centre for International Agricultural Research. Pusat Litbang Hutan Badan Litbang.

Hasan, \& Susila. (2018). Marketing Chain of Ketak (Lygodium circinnatum) and Cultivation Opportunities on Community Land. The paper presented on Join Internasional Comfrence Hydro-Meteorological Disaster Mitigation under Global Change, 29 Nopember.

Indriyanto. (2009). Komposisi Jenis dan Pola Penyebaran Tumbuhan Bawah Pada Komunitas Hutan Yang Dikelola Petani Di Register 19 Provinsi Lampung. Seminar Hasil Penelitian \& Pengabdian Kepada Masyarakat. Jurusan Kehutanan fakultas Pertanian Universitas lampung.

Silalahi. (2016). Keanekaragaman dan distribusi tumbuhan bermanfaat di pekarangan Kampus Universitas Kristen Indonesia, Cawang, Jakarta Jurnal Biologi, 20, 75-82.

Siregar M, Ardaka, \& Hartutiningsih. (2014). Pengaruh jenis media dan zat 
pengatur tumbuh atonik terhadap perkecambahan spora dan pembentukan sporofit Lygodium circinnatum (Burm.F.) Sw. (Schizaeaceae). Buletin Kebun Raya, 17(1), 15-24.

Susila, I.W.W., \& Setyayudi, A. (2017). Peningkatan Pertumbuhan Permudaan Alam Rumput Ketak (Lygodium circinnatum (Burn. F.) Sw.) di Kawasan Hutan Pusuk, KPH Rinjani Barat. Disampaikan dalam Seminar Nasional Perhutanan Sosial dalam Mendukung Kesejahteraan Masyarakat dan Ketahanan Pangan, Tangga. Makassar: Balai Penelitian dan Pengembangan Lingkungan Hidup dan Kehutanan Makassar.

Tauhid, M. (2012). Pengaruh Intensitas Cahaya dan Dosis Pupuk Organik Cair NASA Terhadap Pertumbuhan Bibit Ketak (Lygodium circinatum Burm.F.) Sw.) Cabutan. Skripsi, Program Studi Kehutanan, Jurusan Sosial Ekonomi Kehutanan, Fakultas Pertanian. Universitas Mataram.

Wahyuningsih, E, Faridah, E., \& Budiadi. (2017). Jenis tanaman rambatan untuk pertumbuhan ketak (Lygodium circinatum (Burm.F.) Sw.) di Hutan Alam Pulau Lombok, NTB. Jurnal Sangakareang Mataram, 16-19.

Wahyuningsih, Faridah, E., \& Syahbudin. (2018a). Analisis komposisi dan keanekaragaman tumbuhan pada tapak alami ketak (Lygodium circinatum) di Pulau Lombok, Nusa Tenggara Barat. Dalam: Seminar Nasional Biodiversitas, Species Asli, Endemik dan Introduksi: Perlindungan, Pemanfaatan dan Pengendalian. Surakarta, 99-110.

Wahyuningsih, Faridah, E., \& Syahbudin. (2018b). Asosiasi vegetasi tanaman rambatan ketak (Lygodium circinatum) pada tapak alami di Pulau Lombok, Nusa Tenggara Barat. Dalam: Seminar Nasional Biodiversitas, Species Asli, Endemik dan Introduksi: Perlindungan, Peman- faatan dan Pengendalian. Surakarta, 89-98.

Yuyun, Y. (2015). Potensi agroforestry untuk meningkatkan pendapatan, kemandirian bangsa, dan perbaikan lingkungan. Dalam: Seminar Nasional Agroforestry 2015, Inovasi Agroforestry Mendukung Kemandirian Bangsa. Balai Penelitian dan Pengembangan Teknologi Agroforestry, 1-19. 